\title{
Current foreign and security policy issues regarding stationing nuclear tactical weapons in Italy
}

Questóes atuais em politica externa e de segurança relacionadas ao estacionamento de armas táticas nucleares na Itália

Temas de actualidad en politica exterior y de seguridad relacionados con el estacionamiento de armas nucleares tácticas en Italia

Lili Takács ${ }^{1}$

DOI: $10.5752 /$ P.1809-6182.2020v17n2p2

Received in January $1^{\text {st }}, 2020$ Accepted in May 5, 2020

\begin{abstract}
During the Cold War Rome hosted nuclear weapons to strengthen the international ranking of the country, hoping that it provides opportunity to restore trust in Italy. Although the original reasons of hosting U.S. nuclear weapons disappeared at the end of the Cold War, Italy is not actively promoting nuclear disarmament.

Keywords: Italy. United States. Nuclear weapons. Nuclear disarmament. NATO.

\section{Resumo}

Durante a Guerra Fria, Roma hospedou armas nucleares para fortalecer a classificação internacional do pais, na esperança de que isso proporcione oportunidade para restaurar a confiança na Itália. Embora as razóes originais para hospedar as armas nucleares dos EUA tenham desaparecido, a Itália não está promovendo ativamente o desarmamento nuclear. Palavras chaves: Itália. Estados Unidos. Armas nucleares. Desarmamento nuclear. NATO.

\section{Resumen}

Durante la Guerra Fría, Roma albergó armas nucleares para fortalecer la clasificación internacional del pais, con la esperanza de que brinde la oportunidad de restaurar la confianza en Italia. Aunque las razones originales para albergar armas nucleares estadounidenses desaparecieron, Italia no está promoviendo activamente el desarme nuclear. Palabras clave: Italia. Estados Unidos. Armas nucleares. Desarme nuclear. OTAN.
\end{abstract}

\footnotetext{
1 Lili Takács is a PhD candidate at Doctoral School of Military Sciences at the National University of Public Service in Budapest, Hungary. Her research focuses on Italian foreign and security policy within the Mediterranean region, and Italian-Libyan relations. ORCID: 0000- 0001-9085-6168
} 


\section{Introduction}

According to the North Atlantic Treaty Organization (NATO) Lisbon Summit Declaration issued on 19 November 2010 the Alliance continues to support non-proliferation efforts in order to create a world without nuclear weapons (NATO, 1949; 2010). However, as long as nuclear weapons do exist, NATO remains a nuclear alliance. Apart from the two European nuclear powers (Great Britain, France), nuclear weapons are stationed in five European NATO member states - Belgium, the Netherlands, Turkey, Germany and Italy within the framework of forward-deployment. In the last years several discussions have been unfolded either in the United States (US) or in Europe, whether nuclear weapons could be used in the changed security environment of our days. Since the end of the Cold War the number of tactical nuclear weapons stored in Europe has been significantly reduced, however their further reduction or complete withdrawal from Europe have been subject of intense debates.

Even though estimates indicate that amongst the above-mentioned countries Italy hosts the most nuclear devices and this is the only country with two nuclear bases on its territory, the Italian standpoint regarding nuclear weapons is not well-known. This research aims at displaying Italian standpoint and policies regarding hosting nonstrategic nuclear weapons (NSNW) on Italian soil, with a special emphasis of its foreign and domestic policy implications and the changes that has occurred. In my paper I use the term "nonstrategic nuclear weapons" as nonstrategic (tactical) nuclear weapons referring to short-range weapons. Within the U.S.-Soviet context, this meant lan- d-based missiles with a range of less than 500 $\mathrm{km}$ and air- and sea-launched weapons with a range of less than $600 \mathrm{~km}$, that were not suited for strategic missions because they lacked the range to reach targets inside the Soviet Union (or, for Soviet weapons, targets inside the United States). They were often small enough to be deployed with troops in the field or at forward bases, the U.S. and the Union of Soviet Socialist Republics (USSR) could have used them to attack targets in the theatre of the conflict, or on the battlefield itself, to support more limited military missions. (WOOLF, 2019)

In my paper I intend to analyse Italy's position regarding hosting nuclear weapons based on Robert Putnam's logic of two-level games that connects domestic politics and international relations, one influencing the other. I argue that there are significant differences of the role domestic politics between the Cold War and the post-Cold War period regarding Italian nuclear policies. Putnam states that national governments have to participate in two-level games (domestic and international level) and cannot concentrate only on one of the levels while neglecting the other. International agreements (in our case: hosting US NSNWs) need to be adopted by national legislation (formal ratification) and by the public (informal ratification). (PUTNAM, 1988).

Resorting to Putnam's theory my hypothesis is that in this specific area of politics domestic politics contributed to the governments' choices without the need of formal ratification during the Cold War period, however, in the New World either formal or informal ratification would be more needed. Using the methodology of document analysis this research is based on governmental and parliamentary sources, news items, speeches, interviews and 
reports. Due to length limit I display the major 'milestones' of Italian nuclear policy from the arrival to nuclear weapons to Italy in the fifties until the $1^{\text {st }}$ Conte-government.

\section{Types of tactical nuclear weapons stored in Italion territory}

The first nuclear weapons were delivered to North-Eastern Italy in 1957: nuclear warheads for the Corporal and Honest John rockets were assigned to the American Southern European Task Force (SETAF). Negotiations leading to the 1955 creation of SETAF constituted a precedent for future negotiations for both countries. From the one hand Italy tried to present the agreement as a result of a multilateral NATO initiative, not as a U.S.- Italy bilateral one in order to minimize potential hostile repercussions from the Soviet Union. From the other hand Italy aspired to reduce the costs of hosting American troops on its territory, expecting to obtain certain compensation to be used to develop Italian forces (NUTI, 2011). From 1959 to 1960, 30 U.S. Jupiter intermediate range ballistic missiles (IRBMs) with 1.45-megaton thermonuclear warheads were deployed to Italy as part of the Eisenhower-administration's nuclear arsenal modernisation programme. These missiles were dismantled in April 1963, six month after the Cuban Missile Crisis was resolved. From the beginning of the sixties Italy hosted antiaircraft Nike-Hercules missiles with W-31 nuclear warheads with yields of 2, 20, and 40 kilotons positioned in the northern part of Italy; nuclear landmines - atomic demolition munitions - positioned on the Yugoslavian border; gravity bombs and several dual-use weapons (e.g. Starfighter fighter-bombers) (FORADORI, 2012)

At the end of the Cold War the United States opted for the radical reduction of its several thousand nuclear weapons stored in Europe. According to experts about 60-90 B-61 gravity bombs can be hosted by Italy (NORRIS; KRISTENSEN, 2012).

\section{Hosting nuclear weapons, as a tool of increasing international ronking during the Cold Wor}

After the Second World Ward Italy concentrated its efforts on avoiding a punitive peace treaty, which was an essential step for reconstructing its destroyed economy and for (re)creating political stability to (re)secure its shattered international status. It must be highlighted that post-World War Italian foreign policy was based on the pursuit of counterbalancing the effects of the peace treaty (HALMOSY, 1982). As Italy integrated into the Western block, the bipolar environment became the decisive cleavage in domestic policy as well, having a direct influence on Italian foreign policy behaviour.

After nuclear bombs were dropped on Hiroshima and Nagasaki the civil and military sphere agreed that Italy's international ranking would be adversely affected by the nuclear era thus resulting in the country's further marginalization within the international arena (NUTI, 2011). This opinion was embraced by the Italian political regime as well, thereby when formulating foreign policy goals during the bipolar era the will of compensating the damaged international status always came in the limelight, this concept became the basis of Italy's military nuclear policy during the Cold War. 
After the nuclear revolution of the fifties, Italian nuclear policy was based on strengthening transatlantic relations which was seen as the main source of accessing nuclear technology and reaching any kind of nuclear power status (NUTI, 2011). As far as nuclear sharing remained in the centre of debates regarding transatlantic security, Italy lobbied intensively within NATO for the joint control of nuclear weapons, since compared to Italy's real international ranking it would have guaranteed Rome bigger influence on decision-making about the eventual launch of nuclear weapons. This behaviour (lobbying for the joint control without the joint burden-sharing) can be interpreted as the externalization of the internal constraints (see later) (ISERNIA; LONGO, 2017), minimizing demands from the outside that could change the domestic order, thus justifying free riding behaviour in international institutions, which in Putnam's theory suggests the lack of will to enlarge the domestic win-set, and using tied-hand behaviour (PUTNAM, 1988)

The Kennedy administration's decision to gradually implement changes in its nuclear policy impacted Italy directly. From the one hand, as the U.S backed away from the concept of nuclear sharing Italy was drifting away from nuclear membership (according to its own interpretation). From the other hand the fact that the U.S. decided to give up nuclear sharing in favour of a non-proliferation treaty with USSR was a serious setback for Italian nuclear policy based on transatlantic cooperation. As a consequence Italy was a fierce opponent of signing the Treaty on the Non-Proliferation of Nuclear Weapons (NPT) (ALBERQUE, 2017). The Italian government proposed a substantial revision and tried to coordinate its efforts with the government of West Germany, however, due to the vicinity of the World War the creation of an Italo-German axis would have evoked bad memories, thus open and fierce German-Italian cooperation did not materialize (MERLINI, 1988). Italy took the position that the treaty would de facto consolidate existing differences within Western European states by using 'nuclear state', 'non-nuclear state' classification, (in Italian interpretation it would have meant permanent Italian military inferiority to France), hence it would hinder the deepening of European integration. As a consequence Rome lobbied for a limited-term treaty which would have given possibility to renegotiate the terms of statuses.

Signing the NPT led to the supervision of Italian nuclear policy: in order to compensate its exclusion from the inner circle Rome became a fierce supporter of the deployment of new weapons (NJØLSTAD, 2005). The aim of the support of the deployment of Euromissiles and the activity shown during rearmament process of the so-called second Cold War was to restore the image of a reliable partner which has been damaged once again by Italian economic difficulties of the 70s, consecutive far-left terrorist attacks and domestic politics instability. Thus in this period the aim of Italian nuclear policy was even more to counterbalance and exploit the negative image caused by domestic policy problems, not to gain domestic political support.

Based on this strategic thinking it is hardly surprising that Italy was the only Western European country that tried to have a real dual key arrangement for the control of the nuclear weapons (NUTI, 2011). According to this concept two ignition keys would have been necessary to actually deploy nuclear weapons: one must have been used by an Italian official, the 
other by an American one, since the possibility of passively accepting decisions made by other power/powers was not satisfactory enough for Rome. However, this mechanism functioned only for one year in 1962, and only regarding the Jupiter missiles, in every other cases the nuclear weapons were under strict US control (FORADORI, 2014).

During the whole Cold War objectives of Italian nuclear policy were evident, either in terms of foreign policy, or in terms of domestic policy. Bipolar environment had a heavy influence on the fragmented, unstable Italian domestic political system (MOLNÁR, 2011), since the most important cleavage between political parties was product of the East-West opposition: the Italian Communist Party (Partito Communista Italiano, PCI) with its 30\% support in average was unable to find any possible coalition partners. When using Putnam's theory this composition of Italian domestic politics resulted in the fact that the 'formal ratification' of Rome's decision wasn't restrained by domestic political issues. PCI assumed the role of supporting anti-nuclear protests and movements which had several effects on Italian nuclear policy. Firstly, due to the fact that it was the Communist party - forced into opposition -supporting protests probably thwarted the evolution of Northern European-like anti-nuclear mass movements (MORO, 2017). Secondly, the objection of nuclear issues by the Communist party strengthened the pro-nuclear position of the often-changing, pro-Western Italian governments, even when the ruling elite was not entirely convinced of the expediency of hosting nuclear weapons. The anti-nuclear stance of PCI made pro-Western orientation more accentuated in Italian politics, thus simplifying the whole issue of hosting nuclear weapons to a choice between "East" and "West".

\section{Current issues of nuclear weapons}

With the end of the Cold War NATO decreased its reliance on nuclear weapons in its defence strategy (NATO, 1999). Since the beginning of the New World Order Italy's national security has not been threatened by such an evident and easily definable challenge which would necessitate the deployment of tactical nuclear weapons. Furthermore, technological development exceeded the practical advantages of using nuclear weapons, currently there are many better solutions (e.g. new generation precision weapons) to address any crises than launching gravity bombs delivered by aircrafts which are exposed to modern air defence systems, however, no nuclear power is willing to disarm its nuclear weapons unilaterally.

Parallel to the changes of the international environment Italian security policy underwent major changes: from the static security policy of the Cold War, concentrating on unidirectional security threat and conventional Article V.-related territorial defence tasks Italian security policy shifted towards a more flexible and active approach (FORADORI, 2014). This resulted that Rome is capable of projecting increased force and Italian armed forces can intervene in distant theatres as well, from security consumer it has become security provider. However, NSNWs cannot be deployed during crisis management and peacekeeping tasks. Italian politics accepted that in the $21^{\text {st }}$ century international ranking is not determined by a country's will to host nuclear weapons on its territory, but by its active participation in handling international crises.

As far as domestic policy is concerned the need to keep the Italian Communist Party in opposition became outdated, PCI transformed 
into an accepted, politically acceptable, coalition-capable social democratic party which doesn't want to change anymore Italy's foreign policy orientation. As a consequence the domestic political win-set ceased to be being limited, Italian governments have to satisfy their domestic voters with the nuclear policy, as well.

\section{Political attitude towards disarmament}

Even though the original reasons for hosting nuclear weapons disappeared, Italy is not particularly active in the field of disarmament. Officially Rome supports nuclear disarmament, however, until a joint position isn't reached amongst NATO member states, it is highly impossible that Italy would take 'unilateral' steps. As a consequence until any NATO member state - e.g. Baltic or Central and Eastern European countries - attributes security values to deploying nuclear weapons to Europe, Italy is willing to slow down or delay any decision regarding their complete withdrawal, since multilateral decisions have traditionally enjoyed advantages to unilateral ones in Italian foreign policy.

Rhetorically Rome fully supports nuclear disarmament, but in spite of the rhetorical support Italian governments haven't submitted any concrete initiative, and it's highly probable that the realization of US preferences will continue to come first in the future. The Italian government didn't even join the other three NATO member states (Germany, Belgium, the Netherlands) that expressed their will to disarm nuclear weapons since 2009-2010 (SPAGNUOLO, 2011). However, in case these countries reach an agreement about the details of disarmament, Italy probably will follow their lead and won't insist on keeping NSNWs in its territory, otherwise it would go against Germany, whose status it has been trying to achieve for a long time. Disarmament hasn't been on the Italian political agenda since the German-Belgian-Dutch initiatives were announced. The IV Berlusconi-government (2008-2011) preferred bilateral relations based on good personal relations of the Prime Minister, it emphasized the importance of the United States. This atlanticist orientation impeded the adoption of a joint statement with pro-disarmament countries against the US. After the fall of the Berlusconi administration, Mario Monti's technocrat government came into power (2011-2013) which didn't have neither adequate mandate, nor adequate leader to address such complex issues. It must be taken into consideration that the Monti government had to deal primarily with the consequences of the economic and the migration crises thus its dual crises management efforts couldn't focus on NSNWs. The same applies for Enrico Letta's then Matteo Renzi's grand coalition governments. After the 2018 parliamentary elections a slightly unorthodox coalition came into power with Lega and MoVimento 5Stelle (M5S). The coalition parties had differing views regarding nuclear weapons: while M5S wanted to rend the Mediterranean region a nuclear-free zone, Lega emphasized the importance of the privileged relations with the US which excludes nuclear disarmament (TREZZA, 2018). Since the governing parties had converging opinions about more urgent issues as well, nuclear questions were off the agenda, under the $1^{\text {st }}$ Conte-government Lega and M5S simply avoided the issue in order to maintain the fragile coalition as long as possible.

Nuclear disarmament is neither on the public, nor on the political agenda. In the centre 
of Italian foreign and security policy we find a dual crisis management mechanism addressing the effects of financial-economic crisis on the one hand, the migration-refugee crisis on the other hand. These issues are more important for the public's subjective perception of security than nuclear weapons deployed to Italian territory which aren't even known by the population.

The population wasn't surveyed until the mid-2000's, even from then only some surveys were conducted having the conclusion that Italians are more pro-disarmament than pro-NSNWs. Resorting to Putnam's theory, we find that there was no need for "informal ratification" by the public of government agreements to host NSNWs. The result of these surveys corroborates with the assumption that the public was left out of decisions regarding nuclear issues: according to the results of the 2006 surveys -conducted 50 years after the first American NSNWs had been deployed to Italy $-32.6 \%$ of the respondents were not aware that nuclear weapons are stored in their country, and only $10.9 \%$ of them knew it for fact. After the respondents were informed that independent experts claim that nuclear weapons are stored in Italian territory, more than half of the respondents expressed concerns about this phenomenon. In lack of information for decades Italian governments avoided informal ratification of their decisions regarding nuclear policy. Amongst the five European countries hosting American nuclear weapons Italy has the biggest number of supporters of the nuclear-free Europe concept (71.5\% of the respondents in 2006) (STRATCOM, 2006). In a 2007 survey $93 \%$ of the respondents claimed that Italy should aim at reducing/disarming nuclear weapons and for $70 \%$ of them the use of nuclear weapons by NATO wouldn't be acceptable under any circumstances (THE SIMONS FOUNDATION, 2007)

\section{Conclusion}

At the end of World War II for decades Rome tried to balance its loss of influence by strengthening transatlantic relations and by hosting American non-strategic nuclear weapons. This commitment had well defined goals during the Cold War: from foreign political point of view it was seen as a tool to get back in the decision-making circle, from internal political point of view it was considered a tool to keep the Italian Communist Party in opposition, thus strengthening the pro-Western orientation of the country. Putnam's two level-game logic can be only partially verified for the Cold War period Italian nuclear policy: neither formal, nor informal ratification of government agreements were needed: the structure of Italy' domestic political arena was shaped by bipolar logic, thus the Communist Party was forced into opposition, the formal ratification of agreements was guaranteed. In this period there was basically no need for informal ratification of government agreements about NSNWs, since these decisions were made by a small, ruling elite, without informing the public. In the case of Italy international and domestic 'tables' were clearly separated during the Cold War, but in the same time bound together by the fact that any change on the one table would imply radical changes on the other one. Two strategies have been dubbed: the internalization of the external constraints (overlapping domestic political cleavage with the international one, domestic left-right constraint becomes a manifestation of East-West confrontation) and the externalization of the internal constraints (minimizing demands from the outside that could change the domestic order), thus justifying free riding 
behaviour in international institutions. Using Putnam's metaphor by not willing to enlarge the domestic win-set, the preferred behaviour was "tied hands" (ISERNIA; LONGO 2017).

The difference between the security systems of the bipolar and the post-bipolar worlds can be described as structural, as Waltz argued in his structural realism theory (WALTZ, 2000). Since threats and challenges concerning Italy's security the most cannot be addressed by deploying non-strategic nuclear weapons, their military importance disappeared. When the Cold War ended the original internal policy reason of storing NSNWs disappeared, the PCI became a widely accepted Social Democratic party; as the image of the eternal enemy disappeared, the level of Transatlantic commitment wasn't measured anymore by hosting American nuclear weapons, as a consequence Italian foreign policy notions changed. In the New World Order as the Italian political system changed, the need of formal ratification appeared. Parallel to this the public gained more information about nuclear issues, thus the need of informal ratification appeared, as well. However, due to the changes in the party system, the number of cleavages between political parties skyrocketed, but in the same time nuclear policy disappeared from the political agenda, as more pressing issues needed to be solved (e.g. economic and financial problems, unemployment, etc).

When analysing the main findings of this paper it must be taken into consideration that nuclear policy had a special place in the Italian political agenda: during the Cold War - due to the military values and the 'power' status attributed to nuclear weapons - it was higher on the agenda, however, the public and a significant part of the political sphere was not informed about it. After the Cold War the values attributed to NSNWs declined, thus the topic slipped down from the agenda, but more information became known for the public and the political spheres, as well.

\section{References}

ALBERQUE, William. The NPT and the origins of NATO's nucelar sharing arrangements. Proliferation Papers, n. 57, p. $1-58,2017$.

FORADORI, Paolo. Reluctant disarmer: Italy's ambiguous attitude toward NATO's nuclear weapons policy. European Security, v. 23, n. 1, p. 33-36, 2014.

FORADORI, Paolo. Tactical Nuclear Weapons in Italy: Striking a Balance between Disarmament Aspirations and Alliance Obligations. The Nonproliferation Review, v. 19, n. 1, p. 13-29, 2012. HALMOSY, Dénes. Nemzetközi szerződések 1945-1982. A második világháború utáni korszak legfontosabb külpolitikai szerződései, Közgazdasági és Jogi Könyvkiadó: Budapest, p. 105-113, 1982.

ISERNIA, Pierangelo; LONGO, Francesca. The Italian foreign policy: challenges and continuities. Rivista Italiana di Scienza Politica, v. 47, Special Issue 2017, p. 107-124.

MERLINI, Cesare. A concise history of nuclear Italy. The International Spectator: Italian Journal of International Affairs, v. 23, n. 3, p. 135-152, 1988.

MOLNÁR, Anna. Olaszország története a második köztársaság idején. Áron Kiadó: Budapest, 2011.

MORO, Renato. Against the Euromissiles: Anti-nuclear Movements in 1980s Italy (1979-1984). In: BINI, Elisabetta, LONDERO, Igor (ed). Nuclear Italy: An International History of Italian Nuclear Policies during the Cold War. EUT, Edizioni Universitá di Trieste: Trieste, 2017, p. 199-211.

NATO. Strategic Concept. North Atlantic Treaty Organization, 24 apr. 1999. Available at: https://www.nato.int/cps/ie/ natohq/official_texts_27433.htm. Last accessed: 04 feb. 2019. NATO. The North Atlantic Treaty. Original text. 4 apr. 1949. Available at: https://www.nato.int/cps/en/natolive/offcial_texts_17120.htm. Last accessed: 23 jan. 2019.

NATO. Lisbon Summit Declaration. Original text. 20. nov. 2010. Available at: https://www.nato.int/cps/en/natolive/offcial_texts_68828.htm Last accessed: 14 oct. 2020.

NJØLSTAD, Olav (ed.). The Last Decade of the Cold War: From Conflict Escalation to Conflict Transformation. Frank Cass: London-New York, 2005.

NORRIS, Robert S.; KRISTENSEN, Hans M. US tactical nuclear weapons in Europe. Bulletin of the Atomic Scientists, v. 61, n. 1, p. 69, 2012 
NUTI, Leopoldo. Italy's nuclear choices. UNISCI Discussion Papers, n. 25, p. 170-172, 2011.

PUTNAM, Robert. Diplomacy and Domestic Politics: The Logic of Two-Level Games. International Organization, v. 42, n. 3, 1988, p. 427-460.

SPAGNUOLO, Laura. Italy's Tactical Nuclear Weapons. BASIC, NATO's nuclear posture, 20 may. 2011. Available at: https://basicint.org/publications/laura-spagnuolo-research-and-policy-officer/2011/italys-tactical-nuclear-weapons. Last accessed: 04 feb. 2019.

STRATCOM. Nuclear Weapons in Europe: Survey Results in Five European Countries. Strategic Communications, 26 may 2006. Available at: http://www.nonaumissilem51.org/ telechargements/R\%E9sultats\%20Sondages\%20OTAN.pdf. last accessed: 04 feb. 2019.
THE SIMONS FOUNDATION. Global Public Opinion on Nuclear Weapons. The Simons Foundation, 2007. Available at: http://www.thesimonsfoundation.ca/sites/default/ files/2007\%20Poll\%20on\%20Global\%20Public\%20Opinion\%20on\%20Attitudes\%20Towards\%20Nuclear\%20Weapons_0.pdf. Last accessed: 14 feb. 2019.

TREZZA, Carlo. M5S/Lega: linee di politica estera parzialmente convergenti, Affari Internazionali, 08 oct. 2018. Available at: https:/www.affarinternazionali.it/2018/10/m5s-lega-politica-estera/. Last accessed: 05 feb. 2019.

WALTZ, Kenneth N.. Structural Realism after the Cold War. Quarterly Journal: International Security, v. 25, n. 1, p. 5-41, 2000.

WOOLF, Amy F. Nonstrategic Nuclear Weapons. Congressional Research Service, 2019, available at: https:/fas.org/ sgp/crs/nuke/RL32572.pdf. Last accessed: 07 apr. 2020. 